Article

\title{
Is a European Practice of Mass Atrocity Prevention Emerging? The European Union, Responsibility to Protect and the 2011 Libya Crisis
}

\author{
Chiara De Franco ${ }^{1, *}$ and Annemarie Peen Rodt ${ }^{2}$ \\ ${ }^{1}$ Department of Political Science and Public Management, University of Southern Denmark, 5230 Odense M, Denmark; \\ E-Mail: cdf@sam.sdu.dk \\ ${ }^{2}$ Institute for Strategy, Royal Danish Defence College, 2100 Copenhagen, Denmark; E-Mail: ifs-10@fak.dk \\ * Corresponding author
}

Submitted: 7 May 2015 | In Revised Form: 13 July 2015 | Accepted: 15 July 2015 |

Published: 26 November 2015

\begin{abstract}
Observers have classified the European Union (EU) as reluctant in its implementation of the "Responsibility to Protect" (R2P) (Task Force on the EU Prevention of Mass Atrocities, 2013). This contribution revisits that argument by employing a more nuanced interpretation of norm implementation than the binary conceptualisation typically applied. By appraising EU reactions to the 2011 Libyan crisis, we investigate whether a "European practice of mass atrocity prevention" is emerging and if so how this relates - or not-to R2P. We do this by investigating EU practices seeking to protect people from genocide, ethnic cleansing, war crimes and crimes against humanity-paying particular attention to the three pillars and four policy areas included in the R2P framework (ICISS, 2001). Our review of EU responses to Libya seeks to unveil whether and if so how EU practice related to mass atrocity prevention in that country rejected, adopted or indeed adapted R2P. The enquiry appraises both how R2P mattered to the EU response and how the Libya crisis affected the Union's approach to mass atrocity prevention and within it R2P. In this way, the study asks how norms can change practice, but also how practice can change norms. As such, our focus is on the inter-relationship between principles and practices of protection.
\end{abstract}

\section{Keywords}

European Union (EU); Libya; mass atrocity prevention; norm implementation; practice turn; Responsibility to Protect (R2P)

Issue

This article is part of the special issue "Mass Atrocity Prevention", edited by Professor Karen E. Smith (London School of Economics and Political Science, UK).

(C) 2015 by the authors; licensee Cogitatio (Lisbon, Portugal). This article is licensed under a Creative Commons Attribution 4.0 International License (CC BY).

\section{Introduction}

The "Responsibility to Protect" (R2P) is an internationally endorsed yet disputed approach to balancing respect for state sovereignty with the perceived need at times to circumvent it to protect people (Bellamy, 2011). It proposes that states have the primary responsibility to protect their populations (Pillar One), but also that the international community should intervene to support (Pillar Two) or-if necessary-take over that responsibility (Pillar Three), when a state is unable or unwilling to protect its population from genocide, ethnic cleansing, war crimes and/or crimes against humanity (ICISS, 2001; UN, 2005). From its inception, R2P sought to institutionalise these limitations to state sovereignty and thereby pave the way for more effective international practices ${ }^{1}$ of protection, overcoming the

\footnotetext{
${ }^{1}$ In this article we use the term "practices" with reference to the so-called "practice turn" in International Relations. We therefore define practices as "socially meaningful patterns of action, which, in being performed more or less competently,
} 
stumbling blocks encountered by the previously proposed principle of "humanitarian intervention". R2P called for a comprehensive reframing of political, economic, judicial and only in the last instance military responses to (expected) mass atrocity situations, amounting to what Martin Gilbert called "the most significant adjustment to sovereignty in 360 years" (Evans, 2011).

Significant efforts by the norm's entrepreneurs brought about positive responses in several international fora, including early endorsement by the United Nations (UN) General Assembly and Security Council. Nevertheless, R2P remains at an emerging stage and is still-perhaps even increasingly-controversial. The logic of contestedness (Wiener \& Puetter, 2009), which has prevailed particularly after NATO's 2011 intervention in Libya, has affected the very meaning of R2P-to its supporters as well as its critics. Among the former, some are now framing the norm in a substantially different way; that is, as an agenda to catalyse political will to "do something", but no longer challenging the Westphalian state system's guarding of sovereignty first and foremost. For example, since her appointment the current UN Special Adviser for R2P, Jennifer Welsh, has emphasised the importance of Pillar One and Two and downplayed military action under Pillar Three, i.e. against the will of the target state (The Stanley Foundation, 2013). Instead she has presented R2P as a statecentred norm, which may mobilise a "sense of duty" towards endangered populations but at the same time renews respect for state sovereignty. ${ }^{2}$

The starting point for this enquiry is that, as with any emerging norm, the meaning of R2P is deemed to evolve through practice. $^{3}$ The content of a norm is shaped by "contestation" (Wiener, 2008) but also "implementation" (Betts \& Orchard, 2014). This enquiry digs deeper into the evolution of R2P by focusing on how it is implemented-in part if not necessarily in full. The goal is to ascertain how-if at all-R2P relates to (changing) practices of protection. To this end, we conceptualise implementation as a non-binary, multifaceted and dynamic two-way process, and explore

simultaneously embody, act out, and possibly reify background knowledge and discourse in and on the material world" (Adler \& Pouliot, 2011, p. 4). To us, actions seeking to prevent, react to or rebuild societies after mass atrocity situations are practices in this sense.

2 Jennifer Welsh, statements made at the Civil Society Dialogue Network Meeting, "The UN, the EU and the Responsibility to Protect: Challenges and Opportunities", Tuesday 10 March 2015.

3 We understand norms as "structures of meaning in use" (Wiener, 2009, p. 176) that evolve interactively (Wiener, 2009, p. 176) so that "norm erosion rather than the "power" of norms will eventually carry the day" (Wiener, 2009, p. 176). Such a definition is useful also to understand how "norms" and "practices" (as defined earlier) are mutually constitutive. how European Union (EU) principles and practices related to mass atrocity prevention are evolving, thereby perhaps giving R2P a specific meaning in the EU context.

For a truly comprehensive analysis, one should assess EU implementation of R2P across preventive, reactive and rebuilding policies. Recognising, however, that prevention and rebuilding are long-term and structural as well as short-term and operational activities, an assessment of such policies towards Libya would require a broader evaluation of EU foreign, security and defence as well as neighbourhood, trade, development, human rights and conflict prevention policies over a much longer period of time. This, unfortunately, goes beyond the scope of this contribution. We do, however, provide a piece of this puzzle in our appraisal of the EU's reactive policies, ranging from political and economic interventions to military responses to human security challenges in Libya during and shortly after the crisis in 2011.

Libya is an important case in point; first and foremost, because of the serious threat the recent crisis brought (and still brings) to people in that country. Moreover, NATO's 2011 intervention has been promoted by some as a clear-cut case of successful R2P implementation (Evans, 2011), whilst others have accused it of killing the concept altogether (Rieff, 2011). Thus, it is a useful place to start unpacking the all too often binary assessment of R2P implementation and reflect further on the multi-dimensional relationship between principles and practices in this regard. The armed intervention in Libya changed several UN members' attitude towards R2P (Thakur, 2013), and the "norm contestation" (Wiener, 2008) that followed might help explain R2P advocates' change of perspective, as discussed above-and perhaps a changed focus in implementation of certain aspects of the norm, examined below. Moreover, Libya has repeatedly been referred to as a(nother) failure for the EU, as it has been used to illustrate the Union's inability to react to crises-especially by military means (Brattberg, 2011; Manon, 2011). This case is, therefore, selected for its potential to explain (1) if and how the EU has adopted, adapted, or rejected R2P, and (2) how R2P relates to EU practices of mass atrocity prevention during and after the Libya crisis.

Political and academic discussions about R2P implementation in Libya have typically employed a narrow understanding of implementation as a binary unidirectional process and focused primarily on implementation within Pillar Three (Welsh, 2014). Our analysis of the EU's reactive policies during and immediately after the crisis will serve to illuminate lesscovered aspects of R2P's three-pillar prescriptions and help us better understand if and how a "European practice towards mass atrocity prevention" is emerging through the EU. The structure of this contribution is as follows: first, we discuss the role of implementation in 
norm development and diffusion more generally; thereafter, we focus on the implementation of R2P specifically. Here we study one in-depth case-EU response to the 2011 Libyan crisis - taking into account all three pillars of R2P, but focusing on one segment thereof, namely, the Responsibility to React. The analysis is based on a review of the existing literature, open source documentation, and some 30 semi-structured interviews with foreign affairs officials, experts and NGO representatives conducted by the authors in Brussels and Denmark between 2012 and 2015.

\section{Norm Implementation}

Despite having originally been developed to make sense of a complex and dynamic process, the theory of international norm diffusion (Finnemore \& Sikkink, 1998) has translated into a research agenda focusing more on norm acceptance and institutionalisation than on operational implementation (Betts \& Orchard, 2014). This is a problem, first, because norm acceptance is only an intermediate step towards internalisation, which means that the norm has acquired a taken-for-granted character irrespective of the individual beliefs of leaders and officials (Risse \& Sikkink, 1999; Risse, Ropp, \& Sikkink, 2013). Second, such a focus neglects that the process of norm internalisation is not a unidirectional progression from acceptance to compliance, but rather a recursive negotiation of the meaning of that norm, which emerges especially when the norm is sought implemented. In relation to the norm's life cycle, it has been argued that lack or partial implementation hinders "norm cascading" to other actors (Wiener, 2008; Wiener \& Puetter, 2009) and damages the external credibility of norm entrepreneurs (Widmaier \& Grube, 2014). Research on norm "localisation"which refers to contexts "shaped by specific permeable and changeable normative orders" (Zimmerman, 2014, p. 2)-also suggests that norm adoption and rejection are not the only possible outcomes of norm diffusion (Acharya, 2004; Mac Ginty, 2011; Zwingel, 2012). If we focus on the process of internalisation that takes place within an organisation after it has formally accepted a norm (arguably the current state of R2P within the EU), then implementation can be seen as a recursive "writing" of the norm. Far from being a binary development leading to either compliance or non-compliance, implementation is better understood as a process of adaptation to the norm and/or of the norm. It may affect practices in more or less direct or visible ways, often depending on how explicit the reference to the norm is. However, it may also affect the very meaning attached to the norm by the organisation implementing it, with possible repercussions for the institutional and international understanding of that norm. In fact, implementation can become a field of contestation and explain why norms are sometimes understood differ- ently across or indeed within international organisations. In the case of human rights, it has been argued: "different types of norm translation can be distinguished, most importantly reshaping or embedding" (Zimmermann, 2014, p. 2). ${ }^{4}$

Krook and True (2012) argue that it is especially vague norms that enable "their content to be filled in many ways and thereby to be appropriated for a variety of different purposes" (Krook \& True, 2012, p.104). In reality, a norm's ambiguity is all but an objective evaluation and rather the result of negotiated meanings. All norms possess a certain degree of "constructive ambiguity" (Best, 2005; Widmaier \& Grube, 2014), which may be exploited first by entrepreneurs to facilitate international acceptance and then by practitioners to guide or allow for (non)implementation. It is through implementation, indeed, that a norm acquires specificity and precision. But this is also when implementation may become blurry if different parts of the organisation implementing the norm have diverging interests or understandings of what the norm means "in practice".

Betts and Orchard (2014) argue that implementation is "a parallel process to institutionalisation which draws attention to the steps necessary to introduce the new international norm's precepts into formal legal and policy mechanisms within a state or organisation in order to routinise compliance" (Betts \& Orchard, 2014, p. 1). They suggest that the "implementation process results in clear and observable standards, which may be the only clear indication that the norm has in fact been accepted" (Betts \& Orchard, 2014, p. 4) and therefore used as "evidence of successful implementation which is transmitted back to the international level in order to monitor compliance with the norm" (Betts \& Orchard, 2014, pp. 4-5).

Following De Franco, Meyer and Smith (2015), we distinguish between three different forms of norm implementation: programmatic, bureaucratic and operational. The first (programmatic implementation) refers to how speeches, statements and strategy documents produced by influential actors within an organisation promote a norm internally and externally. The second (bureaucratic implementation) accounts for how bureaucratic structures and procedures of decisionmaking and policy development respond to the norm. The third (operational implementation) refers to the norm's mainstreaming into existing policies and resource allocation. As our focus is on reactive "practices", the following will mainly focus on operational implementation, but when appropriate include speeches and statements that qualify as short-term programmatic implementation in guidelines for further action (operational implementation), as illustrated in Table 1.

However, these categories should not be taken as

\footnotetext{
${ }^{4}$ Emphasis in original.
} 
clear-cut categories of compliance to specific R2P prescriptions. Such standards would inevitably reflect expectations about what the norm should mean in practice. This methodology would be appropriate if we had a binary understanding of implementation, but not as we approach implementation as the very process by which a norm is reified. In other words, if implementation is a specification and (re)interpretation of the norm, we cannot have pre-fixed standards of compliance. Rather, (at least) part of this research should deal with the intrinsic challenge of finding a way to evaluate implementation. In this article, we have taken on this challenge by examining R2P as a framework structuring action through three pillars and four policy areas and relating this to the EU's practices in a given case. The intention is not to determine causation between R2P and EU practices but to explore relations between (aspects of) the two. Table 1 illustrates how we methodologically examine EU practices during the 2011 Libya crisis in relation to R2P. This approach is tailored to our specific case study and its limited focus on reactive practices. It could be developed further for future research by including medium- and long-term programmatic and bureaucratic implementation as well as the proposed responsibilities to prevent and rebuild.

Table 1. Indicators of EU R2P implementation.

\begin{tabular}{lll}
\hline 1 & Short-term & R2P (incl. three pillar \\
& programmatic & structure and tool \\
implementation & sequencing) promoted in \\
& speeches and statements \\
& delivered by influential EU \\
& actors reacting to \\
& developments in Libya and \\
& providing guidelines for \\
& further action
\end{tabular}

2 Operational implementation
R2P (incl. three pillar
structure and tool
sequencing) evident in political, economic, judicial and/or military practices (incl. policies and resource allocation)

\section{R2P Implementation}

Following the argument above, we focus on implementation to understand what R2P is developing into through related practices reacting to (expected or current) mass atrocities. R2P presents some especially interesting features illustrating how important and yet challenging the study of norm implementation is. First, R2P is an "emerging norm" (De Franco et al., 2015). There has been a series of efforts to operationalise R2P "both within the reasoning as well as the daily work of institutions...to build political support for the concept"
(Vincent \& Wouters, 2008, pp. 6-7). However, since the Libya crisis, to which we shall return, a "logic of contestedness" (Wiener \& Puetter, 2009) has prevailed. This has in particular related to the international community's remedial Responsibility to React, the focus of this enquiry, and to the fora through which this is implemented. Second, R2P is a "principled norm" (Betts \& Orchard, 2014), not creating precise legal obligations and therefore largely depending on implementation to become more specific and precise through practice and precedence. Third, R2P is a "complex norm" (Welsh, 2014) containing more than one set of prescriptions, which "not only apply to different actors (in the case of Pillar One, national governments, and in the case of Pillars Two and Three, to various international actors), but also exist at different levels of specificity" (Welsh, 2014). This means that we can expect substantial variations in the degree and nature of implementation of different prescriptions and that one set of prescriptions therefore may become more heavily "weighted" in the overall understanding of the norm.

Welsh (2014) rightly stresses that "whether or not military intervention occurs is not an appropriate "test" for effectiveness" (2014, p. 136); "R2P's core function, as a norm, is to emphasise what is appropriate and to shine a spotlight on what is deemed inappropriate" (2014, p. 136). R2P is more similar to a "policy agenda" than a "rallying cry" for action (Bellamy in Welsh, 2014, p. 136). Thus, Welsh has argued, R2P's strength should rather be measured "by the degree to which notions of protection are invoked by international actors during times of real or imminent crisis" (Welsh, 2014, p. 136) and how R2P serves "as a catalyst for debate" (Welsh, 2014, p. 136). Therefore, "what the second and third pillars of R2P demand is a "duty of conduct" by members of the international community: to identify when atrocity crimes are being committed (or when there is threat thereof) and to deliberate on how the threepillar framework might apply" (Welsh, 2014, p. 136). Welsh's argument might certainly be influenced by her positive bias towards the norm in her position as UN Special Adviser for R2P, but it retains strength for our purposes in that it identifies challenges of "measuring" R2P implementation and offers some solutions to it. In the following, we examine empirically how R2P's "duty of conduct", as proposed by Welsh, relates to the EU's reactive practices regarding Libya in 2011 . This adds to our more nuanced take on R2P implementation, whilst we explore whether and how a "European practice of mass atrocity prevention" is emerging.

\section{Regional Agency and Mass Atrocity Prevention}

It is important to focus on regional agency-and that of the EU in particular-in relation to mass atrocity prevention for a range of reasons. First, regional actors and arrangements are explicitly recognised in the UN 
Charter (UN, 1945) as important to the maintenance of international peace and security and by the International Commission on Intervention and State Sovereignty (ICISS, 2001) as central to the implementation of R2P specifically. This accredits them legitimacy, authority and responsibility in this regard. Second, regional organisations are becoming increasingly active in security provision; thus, they enhance the range of tools and options available. Third and related, regional organisations increasingly shape the understanding of security challenges and frame responses to them in and beyond their respective regions (Dahl Thruelsen, 2009; Tavares, 2010). Fourth, it has been suggested that regional organisations (can) translate international norms into regional responses to local problems (Dembinski \& Reinold, 2011). Fifth, upon request from UN member states after NATO's intervention in Libya, the UN Secretary-General's Report on "The Role of Regional and Sub-regional Arrangements in Implementing the Responsibility to Protect" discussed this issue specifically, albeit not devoid of ambiguities, which remain important to be considered below. Altogether this suggests that studying regional dimensions of mass atrocity prevention may illuminate how related norms like R2P are implemented and influential (or not).

As a highly integrated and influential regional organisation in Europe, with a normative reach that increasingly seeks to go beyond its borders, the EU is a potentially important regional organisation in this realm. Through the so-called "comprehensive approach" (CA), "effective multilateralism" (EU, 2003) and its substantial powers of attraction as well as pressure and persuasion, the Union increasingly seeks to incorporate significant levels of normative conditionality in its external relations (Manners, 2006). This makes the EU a potential norm implementer/shaper outside as well as inside its borders; hence, its practices may matter to international norms and principles. Not surprisingly, therefore, the EU has been perceived as a particularly suitable candidate for the implementation of mass atrocity prevention through R2P (Vincent \& Wouters, 2008). Finally, as mass atrocities are understood as the anti-thesis to development, the EU, as the world's biggest aid donor is perceived as a key player in the nexus believed by some to exist between development and mass atrocity prevention (Eggleston, 2014).

\section{The EU, R2P and Parallel Principles}

In 2003 the EU introduced an overarching principle to guide its crisis management activities: the so-called "comprehensive approach". This appeared for the first time in the official framework for civil-military cooperation (CMCO) (Council of the European Union, 2003), presented as the conceptual response to the "need for effective coordination of the actions of all relevant EU actors involved in the planning and subsequent imple- mentation of EU's response to the crisis" (Council of the European Union, 2003, p. 2). The European Commission played a vital part in redefining the CA as a conflict-sensitive approach to development cooperation (European Commission, 2011). The successive drafting of the Joint Communication on the EU's Comprehensive Approach to External Conflict and Crises reflected diverging conceptions dividing the European Commission and the Council. While the former has tenaciously insisted on the need to respect development policy's conventional neutrality, the latter has continuously expressed concern that too strong a focus on political neutrality might lead to a failure to act strategically in the framework of the rebranded Common Security and Defence Policy (CSDP) (Pirozzi, 2013, p. 7).

Meanwhile, the notion of "human security" has become central to the development of EU security policy (Curran, 2015; Dembinski \& Reinold, 2011; Gottwald, 2012; Martin \& Owen, 2010). As outlined by Martin and Owen (2010), not only did the Report on the Implementation of the European Security Strategy (ESS) (Council of the European Union, 2008) explicitly mention human security as a guiding principle of EU external action, it also drew "extensively, and in more detail than in previous texts, on human security ideas, affirming the importance of respect for human rights, and the gender dimension of security" (Martin \& Owen, 2010, p. 217). In its drafting the Council was reportedly influenced by then High Representative for European Foreign and Security Policy (EFSP), Javier Solana; by Finland, which during its 2006 presidency of the EU commissioned a study on the European Security and Defence Policy's (ESDP) relation to human security; and by the European Parliament (Martin \& Owen, 2010, p. 218). Hereafter, human security was mainstreamed especially by the European Commission into initiatives on human rights and policies on small arms and light weapons, non-proliferation, mine action and human trafficking. Following Martin and Owen (2010), the EU's implementation of human security specified the norm in a way that differed slightly from the UN's original conception by combining "physical protection and material security, and situating it firmly within a crisis management and a conflict resolution policy frame" (Martin \& Owen, 2010, p. 219).

Moreover, when the UN released its operational concept for "protection of civilians" (POC) in peacekeeping operations in 2010, the EU not only welcomed but adopted it in its own Guidelines for Protection of Civilians in CSDP Missions and Operations. Like the UN, the EU conceptualised protection of civilians as a comprehensive and long-term effort by national and international actors in cooperation, combining military and non-military measures, not only providing direct protection from physical violence but also protection through political processes and establishment of protective environments, thus, seeking to address the root causes of threats to civilians. In this way, the EU's op- 
erationalisation of POC highlighted human security concerns like protection of human rights, essential services and resources in a stable, secure and just environment as well as protection from physical violence and mass atrocities (De Benedictis, 2015).

To some scholars (Dembinski \& Reinold, 2011), the rise of human security in EU security culture and CSDP stated objectives can be explained by the 2005 World Summit Outcome (UN, 2005) and its adoption of R2P. After all, an official and explicit reference to R2P appears already in the EU's 2005 Consensus on Development (EU, 2005). Likewise, the 2008 report on the implementation of the ESS links the two concepts by stressing the importance of human security, whilst at the same time recognising that "sovereign governments must take responsibility for the consequences of their actions and hold a shared responsibility to protect populations from genocide, war crimes, ethnic cleansing and crimes against humanity" (Council of the European Union, 2008, p. 2).

Surprisingly though, scholars have found the EU reluctant to mainstream the implementation of R2P (De Franco et al., 2015; Gottwald, 2012; Task Force on the EU Prevention of Mass Atrocities, 2013). Alongside a perceived lack of coordination of organs, instruments and policies, the EU has been accused of lacking a clear strategy (Coelmont, 2014), necessary capacities and political will to protect people outside its borders and prevent mass atrocities (Biscop, 2011). A similar view was expressed by NGO officials interviewed by the authors in 2012 and 2013. This, despite the enhanced and increasingly formalised competencies of the EU High Representative/Vice President of the Commission and the European Union External Action Service, established as the Lisbon Treaty initiated a number of changes intended to increase the Union's shared will, ability, voice and engagement in external relations (EU, 2008). Disparate initiatives continue to take place, but scholars and practitioners still seem to agree that the EU lacks political unity and strategic direction. As a result, its principles and practices related to mass atrocity prevention risk remaining un-coordinated at best and un-cooperative at worst-inside as well as outside the Union (De Baere, 2012; Dembinski \& Reinold, 2011; Task Force on the EU Prevention of Mass Atrocities, 2013; Vincent \& Wouters, 2008).

\section{EU Reactions to the 2011 Libya Crisis}

In accordance with the UN Secretary-General's 2011 report, we accept that the EU's "scope, capacity, and authority" constitutes potential for R2P implementation-also beyond the European region. Likewise, we agree that operational implementation of R2P would require preventive, responsive and reconstructive actions across the norm's three-pillar structure, crosscutting various policy areas. This could-as various EU rep- resentatives have argued-correspond with the Union's existing notion of human security and its comprehensive approach to crisis management (including conflict prevention). In the following, we examine the EU's actual reactions to the Libya crisis-including political, economic, judicial and military means-to assess the extent to which a "European practice of mass atrocity prevention" emerged in this case - and if so, how this related to R2P. In so doing, not only do we ascertain whether R2P was rejected or adopted as a full framework for action but we do also explain how R2P has been adapted to existing principles and practices of the EU.

\subsection{Short-Term Programmatic Implementation of R2P}

As the Libyan regime responded increasingly violently to the 2011 rebellion against it, the international community reacted by invoking R2P's measure of "last resort". Security Council Resolution 1973 was historic in that for the first time the UN mandated forceful implementation of R2P's Third Pillar to protect a population believed to be threatened by mass atrocities to be committed by its own government. The resolution authorised "all necessary means" for their protectionagainst the will of Libya's leadership, which was subsequently removed by local rebel forces supported by international use of force. The bombing campaign was initiated by a coalition of willing Western states, with France, the UK and a reluctant US in the lead, supported by regional actors: the Arab League, United Arab Emirates and Qatar. NATO later took over the operation. Initially, the air campaign was relatively restricted, but as it went on, it became increasingly supportive of the rebels' cause to oust Gadhafi, and with that it became increasingly controversial around the world (Dembinski \& Reinold, 2011).

At the beginning of the crisis in February 2011, then High Representative Catherine Ashton condemned the repression of peaceful demonstrators and the violence against and death of civilians in Libya. She went on, in accordance with R2P Pillar One, to urge the Libyan authorities to refrain from any further violence against the population. Shortly after, Council President Herman Van Rompuy acknowledged the EU's own responsibility, in accordance with Pillar Two, to support Libya and protect the Libyan population henceforth. To this end, he stated, "European leaders...acted with swiftness and determination, diplomatically...and militarily" (Van Rompuy, 2011b). Nevertheless, the EU was criticised for its "slow and incoherent" response to the crisis (Gottwald, 2012, p. 5). Gottwald (2012) questioned whether Van Rompuy was speaking of the EU at all in his reference to "European leaders", and if so, whether his assessment was fair. Whether or not he was referring to the Union or to particular member states, Van Rompuy's statement does demonstrate significant support within the EU at the time for R2P's forceful 
implementation, and that amongst its advocates was the then President of the Council. Not only did he stress that R2P was put into action with perseverance and success, but he added that there was "a responsibility to assist the new Libya with the political transition, the reconciliation and the reconstruction of a united country" (Van Rompuy, 2011b).

Critics have argued that the Union's response to the crisis showed a gap between EU rhetoric and action (Gottwald, 2012). However, in diplomacy more generally and according to the R2P framework specifically, rhetoric is action. It is one diplomatic tool among many-a tool, which the EU repeatedly used in response to the Libyan crisis - and as such an indicator of programmatic implementation of $\mathrm{R} 2 \mathrm{P}$, as defined above. Upon the adoption of Resolution 1973, Ashton and Van Rompuy (2011) declared that the EU was "ready to implement this resolution within its mandate and competencies". This statement was supported by the Council, representing all 28 member states, which expressed its satisfaction with the resolution and "underlined its determination to contribute to its implementation". Van Rompuy (2011a) emphasised that "the European Council wants the safety of the Libyan people to be secured by all necessary measures". The Council soon urged Gadhafi to relinquish power, and when the Libyan Contact Group recognised the National Transitional Council (TNC) as the legitimate governing authority in Libya, the EU-itself a member of the Contact Group-supported that decision. Subsequently, both Van Rompuy and Ashton reminded the TNC of their responsibility, as the governing authority, to protect the citizens of Libya and reiterated the EU's Responsibility to Assist them in this endeavour (Pillars One and Two).

In other words, the EU as a whole committed itself explicitly to R2P in response to the Libya crisis. Although there were significant disagreements in the wider international community as well as amongst EU member states about whose responsibility it was to do what and, thus, how R2P should be implemented, the Union's member states did agree to voice their shared support: first, for the Libyan authorities'-initially Gadhafi and later the TNC-Responsibility to Protect all Libya's people (Pillar One); second, the EU's Responsibility to Assist them in this (Pillar Two); and third, only in the last instance and upon the UN's request and mandate for the international community to take over some of that responsibility (Pillar Three). Despite disagreements among the member states (cf. Germany's abstention in the Security Council vote on Resolution 1973), they did reach consensus in the Council and in effect upon the EU's short-term programmatic implementation of R2P in reaction to the Libya crisis.

\subsection{Operational Implementation of R2P}

Despite significant disagreements along the way, the
Union's member states also agreed to launch a series of joint operational responses to the crisis. In March 2011, the Union convened an Extraordinary Council meeting of European leaders in Brussels. At this emergency meeting the Council called for Gadhafi's resignation and welcomed the TNC in his place. Subsequently, the EU opened a liaison office in Benghazi in May and promised further support to the new Libyan authorities in border management and security reform, to the economic, health and education sectors as well as to the Libyan civil society (Gottwald, 2012).

Field experts were deployed inside and on the borders of the country. Frontex Joint Operation Hermes 2011 responded to Union concerns of increased migration flows following the crisis, although it failed to accept or promote any Responsibility to Protect these people. Nevertheless, while the Union was bringing some 5,800 EU citizens home from Libya, EU Commissioner for International Cooperation, Humanitarian Aid and Crisis Response, Kristalina Georgieva, was one of many who reminded the EU of its Responsibility to Protect not only its own citizens but also the Libyan population (Georgieva, 2011).

In 2011 the Strategy for Security and Development in the Sahel had announced EUR24.5 million in EU assistance to Libya, allocated under the European Development Fund, Instrument for Stability, European Neighbourhood Policy Instrument, thematic programmes and budget lines. However, by October 2011 the Commission and certain member states had provided over EUR152 million towards humanitarian aid and civil protection in the country (ECHO, 2011), illustrating the Union's support for and use of non-coercive tools in reaction to the crisis. The EU also implemented a number of coercive sanctions. It adopted and helped enforce UN sanctions, including the arms embargo and targeted sanctions mandated by UN Security Council Resolution 1970 as well as the no-fly zone and extension of the asset freezes added in Resolution 1973. The Union added further sanctions of its own. Overall, some 40 individuals close to the regime, key financial entities, the National Oil Corporation and five of its subsidiaries, the port authorities, and 26 energy firms in Libya were targeted by EU sanctions (Koenig, 2011).

The Union considered military responses as well, but favoured a UN mandate and hoped to support the delivery of humanitarian aid rather than actively engaging in the armed conflict. In April 2011, the EU responded to a request from the UN Office for the Coordination of Humanitarian Affairs and declared itself ready to deploy up to 1,000 personnel to facilitate safe movement and possible evacuation of internally displaced people and assist humanitarian aid access in Libya. HR Ashton clearly stated that this mission was "unlikely" to be deployed, but she argued that if it was requested, it should be ready; hence, she said at the time, planning was initiated (Al Jazeera, 2011). Particu- 
larly relevant to our analysis, is the fact that all EU member states supported the HR's initiation of the operational planning process, although they disagreed profoundly on how such a response should be implemented. For example, Sweden and Finland, both members of the Nordic Battle Group, rejected the idea of its deployment. Meanwhile, UN humanitarian chief, Valerie Amos, expressed concern that the proposed EU force (EUFOR) "blurred lines" between military and humanitarian action and stressed that it should only be called upon as a last resort. In the end, EUFOR Libya was not deployed, as the UN never requested it.

Interviews conducted with EU officials between 2012 and 2013 revealed an organisational culture anchored in a "civilian power" Europe ideal, deeply uncomfortable with forcible humanitarian intervention. Interviewees also stressed that the EU has no legal basis for initiating military operations and is heavily dependent on member states' willingness to mobilise resources, particularly the few countries with an expeditionary model and means of foreign policy. However, the argument most interviewees put forward was that if the "desired outcome is saving lives" then a forcible military intervention might not be the best option. Naturally, variations occurred across interviews with respondents from different parts of the EU system. While officials from the EU Military Staff did not exclude Mass Atrocity Response Operations (MARO) ${ }^{5}$ in principle-they suggested that the Petersberg tasks (incl. peace-enforcement) in fact include MARO. Officials from DG DEVCO, the development agency of the European Commission, stressed rather the importance of non-coercive measures for both prevention of and reaction to mass atrocities.

Overall, in response to this crisis the Union repeatedly stressed the Libyan authorities' protection responsibilities - first to Gadhafi and later to the TNC. It recognised its own responsibilities in this regard too. EU reactions to the crisis ranged across the three pillars and from political and economic measures to considering military options and humanitarian assistance. This indicates a clear correlation, albeit not necessarily causation, between the R2P norm, framework and tools, on the one hand, and the Union's response to the Libyan crisis, on the other-suggesting that the two may indeed have been mutually reinforcing. The EU explicitly supported Pillar One, Two and Three responsibilities to protect the Libyan population in various political statements and operational activities, which indicates the Union's support for the R2P framework as a whole as well as its component parts. There is evidence of short-term programmatic implementation as well as operational norm implementation, which indicates that

${ }^{5}$ MARO operations are a doctrinal concept that is detailed in Appendix B to the US Department of Defence Joint Publication on Peace Operations (DOD, 2012). in this case existing scholarly interpretations of EU R2P implementation are too simplistic. It is worth noting, however, that the EU approach to Pillar Three also in this case seems to emphasise humanitarian assistance and capacity building within the existing crisis management framework, in continuity with the EU's normative agenda on human security, as described by Martin and Owen (2010), rather than more mainstream interpretations of what R2P's Pillar Three should entail. In particular, according to officials from the EEAS multilateral relation division, the Libya crisis revealed different interpretations of Pillar Three among member states and substantial resistance to R2P's limitations to state sovereignty emerged. ${ }^{6}$ Nevertheless, this did not amount to a rejection of R2P altogether nor to absence of joint EU reactions to the crisis in Libya-rather it seemed to shape the nature of the two. As argued above-norm implementation is not simply an either-or question-instead we proposed an alternative approach, which allows for and recognises nuanced implementation or weighting of various aspects of a norm. It makes better analytical sense, we suggest, to thoroughly examine relations between norms and practices, in our case between R2P and EU crisis response in Libya, than to get stuck in chicken-oregg discussions considering correlation vs. causation which does not allow for parallel principles and practices to co-exist.

\section{The EU's Parallel Protection Principles and Practices after Libya}

Having to face another crisis in Mali shortly after the Libya crisis-and partly as a consequence thereof-the EU reconsidered its approach to crisis management and civilian protection. In 2013 the EU Military Committee deemed it necessary to develop a military concept for "POC in EU-led Military Operations", adopted in March 2015. Although its focus was notably on POC rather than $\mathrm{R} 2 \mathrm{P}$, the concept illustrates continued attention to and focus on protection in EU external action. The Union's operationalisation of POC thus runs parallel to the R2P framework, but reveals a continued EU acceptance of and preoccupation with its own responsibility in this regard-if now by another name (De Benedictis, 2015).

Our interviewees confirm increased attention to mass atrocity prevention after the Libya crisis. Intelligence officials at the EU Intelligence Centre, in particular, reported being explicitly "tasked" to monitor risks of mass atrocities in Libya in 2012. Likewise, the drafting of the Joint Communication on the EU's Comprehensive Approach was given new impulse. The document-released in December 2013-does not mention R2P explicitly but arguably integrates parts of the R2P

\footnotetext{
${ }^{6}$ Interviews conducted in Brussels in June 2012.
} 
framework into the CA. It expands the CA's scope to include all "stages of the conflict cycle" (European Commission \& High Representative of CFSP, 2013, p. 2), including those of conflict prevention and sustainable long-term development, and strengthens the connection between security and development, also at the core of the EU's initial interpretation of R2P. This too indicates an overall normative agenda seeking to incorporate and integrate parallel principles in practice.

The practical inter-relationship between human security, POC, R2P and CA became apparent with the first implementation of CA after its formalisation; that is, in EU reactions to the Mali crisis. To operationalise the $\mathrm{CA}$, the EU Delegation in Bamako received a short-term stabilisation package of EUR20 million through the Instrument for Stability, primarily intended to support the "protection of civilians" (European Commission, 2013) by helping the "Malian local authorities, to reestablish the presence of the State" (European Commission, 2013), indicating continued-and preferredEU support for what in R2P terms are Pillars One and Two, as one might have expected from the findings above regarding EU implementation of R2P.

\section{Conclusions}

This article shows how the 2011 Libya crisis in many ways was a revealing moment for EU practices of mass atrocity prevention. During the crisis, the EU operationalised R2P, incorporating its own interpretation of the emerging norm while integrating it into its existing security cultures, structures and policies. The EU did this by adapting R2P to its own needs, traditions and interests. Thus, we take issue with those observers who suggested that the Libya intervention strengthened the hand of those within the EU pushing for more forceful interpretations of the norm (Dembinski \& Reinold, 2011), as well as with those who argued it may have broken the EU consensus on R2P altogether (Brockmeier, Jurtz, \& Junk, 2014). Our findings show rather how the EU has consistently conflated parallel principles like R2P and POC with its comprehensive approach in a way that is consistent with its original approach to human security. That is, as part of its development policy and crisis management activities.

While the use of the human security label has declined, as R2P is now also doing, the way in which R2P was implemented in Libya and the comprehensive approach was formalised to incorporate POC thereafter shows both adoption and adaptation of R2P. Reference to the three-pillar structure is explicit, continuous and apparent, whilst the EU emphasises its responsibility to assist-particularly in preventing and rebuilding, while limiting its considerations regarding the use of the military to crisis management-and particularly humanitarian and technical assistance to fragile states and populations. So, R2P's duty of conduct was adopted in the Libya case, but R2P was at the same time adapted to the Union's existing normative agenda and integrated into the development of the comprehensive approach to conflict and crisis, now including protection of civilians. Different organs and representatives of the EU remain sceptical about the added value of an "R2P lens" - not to mention label-to their ongoing work (De Franco et al., 2015; Task Force on the EU Prevention of Mass Atrocities, 2013). However, R2P has influenced EU crisis response, civilian protection and early warning in and beyond Libya, even if an explicit reference to R2P has become ever more problematic because of the increasing norm contestation after that crisis.

In sum, we show how the conflation of R2P with related principles and practices has placed most of the norm's "weight" on the first two pillars. This is where there has been a wider and stronger consensus among EU institutions and member states since 2005 and still in 2015. In so doing, the EU is contributing (a) to what we propose is a changing conception of the R2P norm, which no longer constitutes the same challenge to traditional notions of sovereignty, and (b) therefore to (European) practices of mass atrocity prevention that are still state- rather than human rights-centred and integrated into development policies and crisis management missions rather than humanitarian interventions.

\section{Acknowledgments}

The authors thank colleagues from the Nordic Protection Platform, European Network for R2P, Danish Political Science Association, European Community Studies Association in Denmark and the Globalisation and Europeanisation Research Group at Roskilde University for feedback on previous drafts of this article. We are also grateful to the Task Force on the EU Prevention of Mass Atrocities and in particular its co-chairs Karen E. Smith and Christoph O. Meyer for promoting research in this area.

\section{Conflict of Interests}

The authors declare no conflict of interests.

\section{References}

Acharya, A. (2004). How ideas spread: whose norms matter? Norm localization and institutional change in Asian regionalism. International Organization, 58(2), 239-275.

Adler, E., \& Pouliot, V. (2011). International practices. Cambridge: Cambridge University Press.

Al Jazeera. (2011). EU mulls military role in Libya. Retrieved from http://www.aljazeera.com/news/ 
africa/2011/04/201141915535323555.html

Ashton, C., \& Van Rompuy, H. (2011). Joint statement on UN Security Council resolution on Libya, 17 March, PCE 072/11 A 110/11. Retrieved from https://www.consilium.europa.eu/uedocs/cms_dat a/docs/pressdata/en/ec/120012.pdf

Bellamy, A. (2011). Global politics and the responsibility to protect. London: Routledge.

Best, J. (2005). The limits of transparency: ambiguity and the history of international finance. Ithaca NY: Cornell University Press.

Betts, A., \& Orchard, P. (2014). Introduction: The normative institutionalization-implementation gap. In A. Betts \& P. Orchard (Eds.), Implementation and world politics: How international norms change practice (pp. 1-28). Oxford: Oxford University Press.

Biscop, S. (2011). Mayhem in the Mediterranean: Three strategic lessons for Europe. Security Policy Brief. Brussels: Egmont Institute. Retrieved from http://www.egmontinstitute.be/publication_article /mayhem-in-the-mediterranean-three-strategiclessons-for-europe

Brattberg, E. (2011). Opportunities lost, opportunities seized: The Libya crisis as Europe's perfect storm. Policy Brief, European Policy Centre, June. Retrieved from https://epc.eu/documents/uploads/ pub_1310_opportunities_lost.pdf

Brockmeier, S., Jurtz, G., \& Junk, J. (2014). Emerging norm and rhetorical tool: Europe and a responsibility to protect. Conflict, Security and Development, 14(4), 429-460.

Coelmont, J. (2014). A comprehensive approach without a security strategy is a hallucination. Retrieved from

http://www.europeangeostrategy.org/2014/05/co mprehensive-approach-without-security-strategyhallucination

Council of the European Union. (2003). Civil-Military Coordination (CMCO). Retrieved from http://regis ter.consilium.europa.eu/doc/srv?|=EN\&f=ST\%2014 457\%202003\%20INIT

Council of the European Union. (2008). Report on the implementation of the European Security Strategy: Providing security in a changing world. S407/08. Retrieved from http://www.consilium.europa.eu/ uedocs/cms_data/docs/pressdata/en/reports/1046 30.pdf

Council of the European Union (2014). Council conclusions on the EU's comprehensive approach. Retrieved from http://www.consilium.europa.eu/ uedocs/cms_Data/docs/pressdata/EN/foraff/14255 2.pdf

Curran, D. (2015). The European Union and the third pillar. In D. Fiott \& J. Koops (Eds.), The responsibility to protect and the third pillar (pp. 146-170). Basingstoke: Palgrave Macmillan.

Dahl Thruelsen, P. (Ed.) (2009). International organiza- tions: Their role in conflict management. Copenhagen: Royal Danish Defence College.

De Baere, G. (2012). Some reflections on the EU and the responsibility to protect. Working Paper No.79, January. Leuven: Leuven Centre for Global Governance Studies.

De Benedictis, V. (2015). Protection of civilians. In J. Rerhl \& G. Glume (Eds.), Handbook: Missions and operations: the common security and defence policy of the European Union (pp.137-140). Vienna: Federal Ministry of Defence and Sports.

De Franco, C., Meyer, C. O., \& Smith, K. E. (2015). Living by example? The European Union and the implementation of the Responsibility to Protect (R2P). Journal of Common Market Studies.

Dembinski, M., \& Reinold, T. (2011). Libya and the future of the Responsibility To Protect: African and European perspectives. PRIF-Report No. 107. Frankfurt: Peace Research Institute.

DOD. (2012). Joint Publication 3-07.3 on Peace Operations. Retrieved from http://fas.org/irp/doddir/ dod/jp3-07-3.pdf

ECHO. (2011). Factsheet Libyan Crisis. 21 June.

Eggleston, E. (2014). Advancing transatlantic linkages on Responsibility to Protect and mass atrocity prevention. Policy Dialogue Brief. The Stanley Foundation. Retrieved from http://www.stanleyfoundat ion.org/publications/pdb/R2PSPC2014PDB1114.pdf

European Commission. (2011). Increasing the impact of EU Development Policy: An agenda for change. $\operatorname{COM(2011)~} 637$ final. Brussels: European Commission. Retrieved from: http://ec.europa.eu/europe aid/news/agenda for change en.htm

European Commission. (2013). EU releases extra $€ 20$ million crisis response and stabilisation support package for Mali. Press Release. Retrieved from http://europa.eu/rapid/press-release_IP-13117_en.htm

European Commission, \& High Representative of CFSP. (2013). Joint communication on the EU's comprehensive approach to external conflict and crises. Retrieved from http://www.eeas.europa.eu/state ments/docs/2013/131211_03_en.pdf

European Union. (2003). A secure Europe in a better world: European security strategy. Brussels, 12 December. Retrieved from http://www.consilium. europa.eu/uedocs/cmsUpload/78367.pdf

European Union. (2005). The European consensus on development. 2006/C 46/01. Retrieved from http://ec.europa.eu/development/body/developm ent_policy_statement/docs/edp_statement_oj_24_ 02_2006_en.pdf

European Union. (2008). The Lisbon Treaty and its implications for CFSP/ESDP Directorate-General for External Policies of the Union, Directorate B - Policy Department - DGExPo/B/PolDep/Note/2008_014. Brussels: European Union. 
Evans, G. (2011). R2P after Libya. Chatham House. Retrieved from: http://www.youtube.com/watch?v=IF 0t5uv9AHY

Finnemore, M., \& Sikkink, K. (1998). International norm dynamics and political change. International Organization, 52(4), 887-917.

Georgieva, K. (2011). Statement on the deteriorating humanitarian situation in Misrata. Retrieved from http://eu-un.europa.eu/articles/en/article_10981_ en.htm

Gottwald, M. (2012). Humanizing security? The EU's Responsibility to Protect in the Libyan crisis. FIIA Working Paper. Helsinki: The Finnish Institute of International Affairs. Retrieved from: www.fiia.fi/ assets/publications/wp75.pdf

International Commission on Intervention and State Sovereignty (ICISS). (2001). Responsibility to Protect. Ottawa: ICISS.

Koenig, N. (2011). The EU and the Libyan crisis: In quest of coherence. The International Spectator, 46(4), 11-30.

Krook, M. L., \& True, J. (2012). Rethinking the life cycles of international norms: The United Nations and the global promotion of gender equality. European Journal of International Relations, 18(1), 103-127.

Mac Ginty, R. (2011). International peacebuilding and local resistance. Rethinking peace and conflict. Basingstoke: Palgrave Macmillan.

Manners, I. (2006). European Union "normative power" and the security challenge. European Security, 15(4), 405-421.

Manon, A. (2011). European Defence Policy from Lisbon to Libya. Survival, 53(3), 75-90.

Martin, M., \& Owen, T. (2010). The second generation of human security: Lessons from the UN and EU experience. International Affairs, 86(1), 211-224.

Pirozzi, N. (2013). The EU's comprehensive approach to crisis management. EU Crisis Management Papers Series. Brussels: DCAF.

Rieff, D. (2011). R2P, R.I.P. The New York Times, 7 November. Retrieved from: http://www.nytimes.com/ 2011/11/08/opinion/r2p-rip.html?pagewanted=all

Risse, T., \& Sikkink, K. (1999). The socialization of international human rights norms into domestic practices: Introduction. In T. Risse, S. C. Ropp, \& K. Sikkink (Eds.), The power of human rights: International norms and domestic change (pp. 1-38). Cambridge: Cambridge University Press.

Risse, T., Ropp, S. C., \& Sikkink, K. (Eds.) (2013). The persistent power of human rights: From commitment to compliance. Cambridge: Cambridge University Press.

Task Force on the EU Prevention of Mass Atrocities. (2013). The EU and the prevention of mass atrocities: An assessment of strengths and weaknesses. Budapest: Budapest Centre for the International Prevention of Genocide and Mass Atrocities.
Tavares, R. (2010). Regional security. London: Routledge.

Thakur, R. (2013). R2P after Libya and Syria: Engaging Emerging Powers. The Washington Quarterly, 36(2), 61-76.

The Stanley Foundation. (2013). R2P is dead, long live R2P. The future of the Responsibility to Protect. Courier, Winter. Retrieved from http://www. stanleyfoundation.org/courier.cfm?year $=2013$

United Nations. (1945). Charter of the United Nations, 24 October, 1 UNTS XVI. Retrieved from: http://www.refworld.org/docid/3ae6b3930.html

United Nations. (2005). Resolution adopted by the General Assembly: 2005 World Summit Outcome. UN Doc. A/RES/60/1. New York: United Nations.

UN Secretary-General. (2011). The role of regional and subregional arrangements in implementing the responsibility to protect. Document no. A/65/877, 28 June. New York: United Nations

Van Rompuy, H. (2011a). Address by the President of the European Council to the Paris Summit on support for the Libyan people, Paris, 19 March 2011.

Van Rompuy, H. (2011b). Address by the President of the European Council, H.E. Mr Herman Van Rompuy, at the 66th United Nations General Assembly General Debate, 22 September. Retrieved from http://eu-un.europa.eu/articles/en/article_11 407_en.htm

Vincent, M., \& Wouters, J. (2008). The Responsibility to Protect: Where does the EU stand? Policy Brief No.10, November. Leuven: Centre for Global Governance Studies.

Welsh, J. (2014). Implementing the "Responsibility to Protect": Catalyzing debate and building capacity. In A. Betts \& P. Orchard (Eds.), Implementation and world politics: how international norms change practice (pp. 124-143). Oxford: Oxford University Press.

Whitman, R. G., \& Wolff, S. (2012). The European Union as a global conflict manager. London: Routledge.

Widmaier, W., \& Grube, D. (2014). Presidents, prime ministers and policy rhetoric: The "Credibility Gaps" of Woodrow Wilson and Kevin Rudd in the League of Nations and climate change debates. Political Studies.

Wiener, A. (2008). The invisible constitution of politics. Contested norms and international encounters. Cambridge: Cambridge University Press.

Wiener, A. (2009). Enacting meaning-in-use: Qualitative research on norms and international relations. Review of International Studies, 35, 175-193.

Wiener, A., \& Puetter, U. (2009). The quality of norms is what actors make of it. Critical constructivist research on norms. Journal of International Law and International Relations, 5(1), 1-16.

Zimmermann, L. (2014). Same same or different? Norm diffusion between resistance, compliance, and lo- 
calization in post-conflict states. International Studies Perspectives.

Zwingel, S. (2012). How do norms travel? Theorizing in- ternational women's rights in transnational perspective. International Studies Quarterly, 56(1), 115-129.

\section{About the Authors}

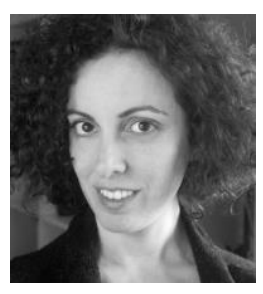

\section{Dr. Chiara De Franco}

Chiara De Franco (PhD European University Institute) is Associate Professor in International Relations, member of the Centre for War Studies and Head of the Master in International Security and Law at the University of Southern Denmark. Previously, she has been Research Fellow in War Studies at King's College London and coordinator of the Task Force for the EU Prevention of Mass Atrocities. She has published books, journal articles and policy papers on the EU and the Responsibility to Protect, the EU and Conflict Prevention, European Military Doctrines and International Media's role in Conflict.

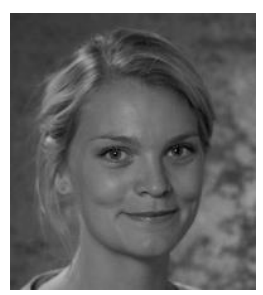

\section{Dr. Annemarie Peen Rodt}

Annemarie Peen Rodt is Associate Professor at the Institute for Strategy, Royal Danish Defence College. Her research appraises Protection of Civilians (POC), Responsibility to Protect (R2P) and Prevention of Mass Atrocities-primarily in wider Europe and Sub-Saharan Africa. Ongoing H2O2O research: "Preventing and Responding to Conflict: Developing EU Civilian Capabilities" and "Improving Effectiveness of Capabilities in EU Conflict Prevention". Collaborative activities include establishing the Nordic Protection Platform and participating in the Task Force on EU Prevention of Mass Atrocities. 